\title{
Feedback of undergraduate nursing students about objective structured practical examination
}

\author{
Amira Mohammed Saed * Nagwa Ibrahim Abbas \\ Faculty of Nursing, Tanta University, Tanta, Gharbia, Egypt
}

Received: June 15, 2016

DOI: $10.5430 /$ jnep.v7n3p68
Accepted: July 28, 2016

URL: http://dx.doi.org/10.5430/jnep.v7n3p68

\begin{abstract}
Background: An essential part of a nursing curriculum is an accurate clinical assessment of nursing students' skills. The objective structured practical examination (OSPE) is the modified version of the Objective Structured Clinical Examination (OSCE) used for a summative assessment of practical knowledge and skills in nursing education. Aim: The current study was undertaken to evaluate the performance and feedback of undergraduate nursing students about OSPE.

Methods: A cross sectional study design was carried out on the students who participated in the OSPE, which was done at the Faculty of Nursing, Tanta University, Egypt. The study included students enrolled in fundamental, medical surgical, critical care nursing, obstetric, and pediatric nursing course. 100 students from each branch were asked to fill structured questionnaire after OSPE.

Results: Overall there were no significant differences in the mean score of students' opinion in relation to the structure and format of examination, conduct of examination, and evaluation of examination compared with the four departments (pediatric, obstetric, fundamental, medical surgical and critical care nursing) $(p=1.000)$.

Conclusions: Students in pediatric, obstetric, fundamental, medical surgical and critical care nursing departments preferred OSPE for evaluating clinical skills and perceived it as more organized, objective, structure, valid, and less anxious. Student's feedback was invaluable regarding need more time at each station. Also, students argued several suggestions for enhancing quality of OSPE in assessing process.
\end{abstract}

Key Words: Objective structured practical examination, Performance, Feedback

\section{INTRODUCTION}

Assessment of clinical competence is an integral issue in clinical health education: assessment of clinical practice is long-standing and receives extra attention in nursing education. ${ }^{[1]}$ The assessment tools need to be effective and crucial to initiate active learning. It has been widely accepted that assessment of students' performance and clinical competence, along with the measurement of knowledge, should contribute to the students' overall evaluation since assessment drives learning. ${ }^{[2]}$
Reliable and valid clinical evaluation should be of a concern to all faculties of nursing and clinical demonstrators. Students need to know, clearly delineated, the specific objectives by which they are being assessed. One type of clinical assessment which meets these criteria is a performance-based assessment. ${ }^{[3-5]}$ The Observed Structured Practical Examination (OSPE) is a type of a performance-based assessment. OSPE is the modified version of the Objective Structured Clinical Examination (OSCE) used for the summative assessment of practical knowledge and skills. ${ }^{[6]}$ In nursing

\footnotetext{
*Correspondence: Amira Mohammed Saed; Email: dramirapediatric@yahoo.com; Address: Faculty of Nursing, Tanta University, Tanta, Gharbia, Egypt.
} 
education, principles of OSPE can be also used in a formative way to enhance skills through simulation. ${ }^{[7]}$

OSPE requires that each student should demonstrate specific skills and attitudes in a simulated clinical environment. OSPE consists of a numbers of stations that enables students to perform certain skills within a deteremined time. It comprised of a series of small skills assessment (stations), each of which is assessed by an evaluator using a predefined, objective grading scheme. ${ }^{[8]}$

OSPE stations produced the strategy for evaluating the student's application of knowledge as well as his or her practical and attitude; the chance to be evaluated on their interview and problem-solving skills; and reflect what the student has taught. In addition, through the assessment of student performances on OSPE, areas of strengths and weaknesses in educational programs have been identified. These advantages allowed OSPE to be extensively used in nursing. ${ }^{[8,9]}$

Significance of the study: A steady increase in count of under graduated students at the Egyptian nursing faculties might increase the opportunity of bad practice that compromises clients conditions, more over the shortage facilities from the clinical sites that could be obstacle the chance of students to perform on clients. Traditional examinations of clinical nursing are not standardized to evaluate clinical performance, and reasoning skills. Nursing students gaining of critical thinking and problem-solving skills are hard to manage with large numbers of students. Moreover, in traditional assessment tool, teachers carrying out the evaluation of student performance tend to give summative grades. So, it is challenging to have such an objective evaluation method to comprehensively evaluate students' practical competencies especially with increased students' number. ${ }^{[10]}$

OSPE should be incorporated within a curriculum in integration with other pertinent student assessment methods. ${ }^{[11]}$ In addition, as a method of practical skills evaluation, the OSPE have a number of benefits. Firstly, it can contain both summative and formative components, in which a judgment or evaluation of student practice is made (summative) followed by the supply of feedback, from which the student can learn (formative). Secondly, as each student is required to perform specific attitudes in a simulated work environment, a firm control over the clinical situation is possible, and at the same time, reflects professional skills in real-life. This control removes the draw problem that appears when students are evaluated within the hospitals with actual clients and the probability of harm that may occur to the clients. OSPE are a precious strategy to assess suitability to performance at the students' expected level of practice within a nursing situation where the value of precise patient assessment is essential. ${ }^{[8,12]}$

There is a diffuse of utilizing of OSPE in specialties of general nursing, pediatric, obstetric, fundamental, and medical surgical nursing has been slow to foster this assessment method and it has only been pressed recently to the Nursing Administration Department, Faculty of Nursing, Tanta University. The present study is intended to assess the feedback of undergraduate nursing students about OSPE used for measuring clinical competence during final nursing courses examinations in pediatric, obstetric, fundamental, medical surgical and critical care nursing departments in order to supply an guide that supports probability of its use in nursing for enhancing students' outcomes.

The aim of the study was to assess feedback of undergraduate nursing students about OSPE.

\section{Materials AND METHOD}

\subsection{Study design}

The study design was institutional-based descriptive cross sectional design.

\subsection{Settings of the study}

This study was carried out at Pediatric, Obstetric, Fundamental, Medical Surgical and Critical Care Nursing Departments, Faculty of Nursing, Tanta University.

\subsection{Study subjects}

The study was conducted from the very beginning of August 2015 to September 2015 within a period of 2 months. During the 2 months period of the study, 400 students were interviewed: 100 students were from Pediatric Department, 100 were students from Obstetric Department, 100 students were from Medical Surgical and Critical Care Nursing, and 100 were students from Fundamental Nursing Department.

\subsection{Tools of data collection}

One tool was used by the researchers to collect the necessary data.

Tool I: Self-administered questionnaire based on Likert scale: This questionnaire was used to assess students' feedback for OSPE. The OSPE feedback questionnaire was developed by Pakhale et al. (2012), ${ }^{[13]}$ it is composed of five parts:

Part I: It included student socio-demographic characteristics as age, and sex.

Part II: It included statements on Likert scale to assess students' feedback for OSPE structure. Structure or format of examination that consisted of 7 items such as the instructions 
were adequate, opportunity for clarification, format of questions, well-structured and sequenced examination covered all types of questions, time allocation was appropriate, and examination was well-organized.

Part III: It included statements on Likert Scale to assess students' feedback for OSPE conduct. It consisted of 5 items such as examination format was more free of stress, variety of structured templates, teachers' absence at stations was free of fright, there is no interruption in the stations, and the presence of examiner on each station facilitated the exam.

Part IV: It included statements on Likert Scale to assess student's feedback for OSPE evaluation. It consisted of 7 items such as examination reduces subjectivity, examination reflect the level of performance, OSPE eliminates factor of luck, result format gave confidence, scoring was transparent and objective; this format reduces chance of failure, and allows more opportunities than the conventional format.

Part V: It included statements on Likert Scale to assess student's feedback for OSPE problems. It consisted of 3 items such as needed more time at each station, limited number of stations, feedback and VOSPE.

\subsection{Procedures}

(1) Before conducting the study, a written permission letter was obtained from the Faculty of Nursing, Tanta University.

(2) Medical ethics: Informed written and oral consent was obtained from students to participate in the study. Confidentiality was assured.

(3) Study tool was given to five juries expert in the field of nursing education before conducting the study to test the validity and clarity of the tools.

(4) Collecting students' feedback: Immediately after the OSPE and in a place out of test, all students received a full explanation for the aim of the study. The questionnaires were distributed to all students to answer with a sufficient comfort to attain students' perception about OSPE. Each student was on a voluntary basis, and all students were assured that the study would be conducted anonymously to protect their confidentiality and information obtained will be confidential and only used for the purpose of the study. Students were given the opportunity to review their individual performances, and they told that who did not share in the study would not be affected in anyway.

(5) The OSPE feedback questionnaire was developed by Pakhale et al. (2012) ${ }^{[13]}$ and modified after a pilot study on 10 students in December 2015 to develop and test OSPE stations and to ensure the applicability and feasibility of the tools.

(6) Students' feedback for OSPE was assessed using Likert Scale (tool). Likert's Scale on a 3-point ranging: "agree", "uncertain", and "disagree".

\subsection{Statistical analysis}

The data were coded, entered and analyzed using SPSS (version 20). Descriptive statistics (frequency numbers and Percentages) identified demographic characteristics and students' responses to the questionnaire. The mean and standard deviation were calculated for total Likert Scale. Chi-square test $\left(\chi^{2}\right)$ was used to analyze the relationships. Statistical significance was set at $p$ value $<.05$.

\section{Results}

Table 1 shows the distribution percentage of the studied students according to their socio-demographic characteristics. As regard to the age, Table 1 shows that the age of the highest percentage of the students $(100 \%)$ ranged from 21 to 23 years old with a mean $20.59 \pm 0.64$ and $20.36 \pm 0.58$ in pediatric and obstetric groups respectively. Moreover, in fundamental and medical surgical and critical care nursing groups, the age of the highest percentages of the students (100\%) ranged from 18 to 20 years old with a mean $18 \pm 0.34$ and $19 \pm$ 0.47 in fundamental and medical surgical and critical care groups respectively. In relation to gender, Table 1 shows that the majority of students $(86 \%, 89 \%, 84 \%$, and $80 \%)$ were female in pediatric, obstetric, fundamental, medical surgical and critical care nursing respectively.

Table 1. Distribution percentage of the studied students according to their socio-demographic characteristics

\begin{tabular}{|c|c|c|c|c|c|c|c|c|}
\hline \multirow{2}{*}{ Characteristics } & \multicolumn{2}{|c|}{ Pediatric Nursing } & \multicolumn{2}{|c|}{ Obstetric Nursing } & \multicolumn{2}{|c|}{ Fundamental Nursing } & \multicolumn{2}{|c|}{ Med-Surgical \& Critical Care Nursing } \\
\hline & $\mathbf{n}$ & $\%$ & $\mathbf{n}$ & $\%$ & $\mathbf{n}$ & $\%$ & $\mathbf{n}$ & $\%$ \\
\hline \multicolumn{9}{|l|}{ Age } \\
\hline $18-20$ & 0.0 & 0.00 & 0.0 & 0.00 & 100 & 100.0 & 100 & 100.0 \\
\hline $21-23$ & 100 & 100.0 & 100 & 100.0 & 0.0 & 0.00 & 0.0 & 0.00 \\
\hline Mean \pm SD & \multicolumn{2}{|c|}{$20.59 \pm 0.64$} & \multicolumn{2}{|c|}{$20.36 \pm 0.58$} & \multicolumn{2}{|c|}{$18 \pm 0.34$} & \multicolumn{2}{|c|}{$19 \pm 0.47$} \\
\hline \multicolumn{9}{|l|}{ Sex } \\
\hline Male & 14 & 14.0 & 11 & 11.0 & 16 & 16.0 & 20 & 20.0 \\
\hline Female & 86 & 86.0 & 89 & 89.0 & 84 & 84.0 & 80 & 80.0 \\
\hline
\end{tabular}


Table 2 shows the distribution percentage of the students' opinion regarding Structure and format of Objective Structured Practical Examination. Table 2 revealed that more than two thirds of students $(72 \%)$ agreed that instructions were adequate in pediatric nursing, fundamental, medical surgical and critical care nursing. Moreover, $45 \%$ of students in obstetric nursing, $51 \%$ in fundamental nursing, $48 \%$ in medical surgical and critical care nursing agreed that there was an opportunity for clarification in examination, while the opinion of $47 \%$ of students in pediatric nursing was uncertain. In addition, $48 \%$ of students in pediatric nursing, $53 \%$ in obstetric nursing, $57 \%$ in fundamental nursing, and $59 \%$ in medical surgical and critical care nursing agreed that there was uniformity of questions. Regarding whether the examination covered all types of questions or not, $52 \%$ of students in pediatric nursing, $58 \%$ in obstetric nursing, and
$64 \%$ in fundamental nursing, medical surgical and critical care nursing agreed in this aspect. Furthermore, $49 \%$ of students in obstetric nursing, $62 \%$ in fundamental nursing, and 54\% in medical surgical and critical care nursing agreed that examination was well-structured and sequenced, while $46 \%$ of students' opinion in pediatric nursing was uncertain. Slightly less than half of the students (43\%) in pediatric nursing, $51 \%$ in obstetric nursing, $39 \%$ in fundamental nursing, and $38 \%$ in medical surgical and critical care nursing agreed that examination time allocation was appropriate. Moreover, about half of the students (49\%) in pediatric nursing, $51 \%$ in fundamental nursing, 56\% in medical surgical and critical care nursing agreed that examination was well-organized while $41 \%$ of the students' opinion in obstetric nursing was uncertain.

Table 2. Distribution percentage of the students' opinion regarding structure and format of objective structured practical examination

\begin{tabular}{|c|c|c|c|c|c|c|c|c|c|}
\hline \multirow{2}{*}{$\begin{array}{l}\text { Structure/Format of } \\
\text { examination }\end{array}$} & \multirow[t]{2}{*}{ Agreement } & \multicolumn{2}{|c|}{$\begin{array}{l}\text { Pediatric Nursing } \\
(\mathrm{n}=100)\end{array}$} & \multicolumn{2}{|c|}{$\begin{array}{l}\text { Obstetric Nursing } \\
(\mathrm{n}=100)\end{array}$} & \multicolumn{2}{|c|}{$\begin{array}{l}\text { Fundamental } \\
\text { Nursing }(n=100)\end{array}$} & \multicolumn{2}{|c|}{$\begin{array}{l}\text { Med-Surgical \& Critical } \\
\text { Care Nursing }(n=100)\end{array}$} \\
\hline & & $\mathbf{n}$ & $\%$ & $\mathbf{n}$ & $\%$ & $\mathbf{n}$ & $\%$ & $\mathbf{n}$ & $\%$ \\
\hline \multirow{3}{*}{$\begin{array}{l}\text { Instructions were } \\
\text { adequate }\end{array}$} & Agree & 72 & 72.0 & 76 & 76.0 & 72 & 72.0 & 72 & 72.0 \\
\hline & Uncertain & 21 & 21.0 & 13 & 13.0 & 11 & 11.0 & 22 & 22.0 \\
\hline & Disagree & 7 & 7.0 & 11 & 11.0 & 7 & 7.0 & 6 & 6.0 \\
\hline \multirow{3}{*}{$\begin{array}{l}\text { Opportunity for clarify- } \\
\text { cation }\end{array}$} & Agree & 41 & 41.0 & 45 & 45.0 & 51 & 51.0 & 48 & 48.0 \\
\hline & Uncertain & 47 & 47.0 & 43 & 43.0 & 28 & 28.0 & 44 & 44.0 \\
\hline & Disagree & 12 & 12.0 & 12 & 12.0 & 11 & 11.0 & 8 & 8.0 \\
\hline \multirow{3}{*}{ Uniformity of questions } & Agree & 48 & 48.0 & 53 & 53.0 & 57 & 57.0 & 59 & 59.0 \\
\hline & Uncertain & 34 & 34.0 & 27 & 27.0 & 17 & 17.0 & 16 & 16.0 \\
\hline & Disagree & 18 & 18.0 & 20 & 20.0 & 16 & 16.0 & 25 & 25.0 \\
\hline \multirow{3}{*}{$\begin{array}{l}\text { Examination covered all } \\
\text { types of questions }\end{array}$} & Agree & 52 & 52.0 & 58 & 58.0 & 64 & 64.0 & 46 & 46.0 \\
\hline & Uncertain & 27 & 27.0 & 22 & 22.0 & 20 & 20.0 & 37 & 37.0 \\
\hline & Disagree & 21 & 21.0 & 20 & 20.0 & 6 & 6.0 & 17 & 17.0 \\
\hline \multirow{3}{*}{$\begin{array}{l}\text { Well-structured and } \\
\text { sequenced }\end{array}$} & Agree & 42 & 42.0 & 49 & 49.0 & 62 & 62.0 & 54 & 54.0 \\
\hline & Uncertain & 46 & 46.0 & 34 & 34.0 & 22 & 22.0 & 25 & 25.0 \\
\hline & Disagree & 12 & 12.0 & 17 & 17.0 & 6 & 6.0 & 21 & 21.0 \\
\hline \multirow{3}{*}{$\begin{array}{l}\text { Time allocation was } \\
\text { appropriate }\end{array}$} & Agree & 43 & 43.0 & 51 & 51.0 & 39 & 39.0 & 38 & 38.0 \\
\hline & Uncertain & 43 & 43.0 & 30 & 30.0 & 23 & 23.0 & 35 & 35.0 \\
\hline & Disagree & 14 & 14.0 & 19 & 19.0 & 28 & 28.0 & 27 & 27.0 \\
\hline \multirow{3}{*}{$\begin{array}{l}\text { Examination was well } \\
\text { organized }\end{array}$} & Agree & 49 & 49.0 & 40 & 40.0 & 51 & 51.0 & 56 & 56.0 \\
\hline & Uncertain & 33 & 33.0 & 41 & 41.0 & 27 & 27.0 & 28 & 28.0 \\
\hline & Disagree & 18 & 18.0 & 19 & 19.0 & 12 & 12.0 & 16 & 16.0 \\
\hline
\end{tabular}

Table 3 shows the distribution percentage of the students' opinion regarding the conduct of Objective Structured Practical Examination. Slightly less than two thirds of students in pediatric nursing $(62 \%), 51 \%$ in obstetric nursing, $65 \%$ in fundamental nursing, and $69 \%$ in medical surgical and critical care nursing agreed that examination format was more stress free. Moreover, $41 \%, 45 \%, 69 \%$, and $47 \%$ of students in pediatric, obstetric, fundamental, and medical surgical and 
critical care nursing agreed that the presence of examiner in each station facilitates the exam respectively. The Table also revealed that $50 \%, 34 \%, 38 \%$, and $39 \%$ of students in fundamental nursing, pediatric nursing, obstetric, and medical surgical and critical care nursing agreed that there was a variety of structured templates in examination respectively. Furthermore, $50 \%$ of the students in fundamental nursing agreed that teachers' absence at the stations was fright free while the opinion of $33 \%, 38 \%$, and $39 \%$ in pediatric nursing, obstetric, in medical surgical and critical care nursing was uncertain. Half of the students in fundamental and medical surgical and critical care nursing (50\%) agreed that there was no interruption in the stations while $43 \%$ and $36 \%$ of students' opinion in pediatric, obstetric nursing was agreed respectively.

Table 4 presents the distribution percentage of students' opinion regarding the evaluation Objective Structured Practical Examination. The Table revealed that 59\%, 48\%, 36\%, and $60 \%$ of students in pediatric, obstetric, fundamental, and medical surgical and critical care nursing agreed that examination reduces the subjectivity respectively. In addition, 39\% in pediatric nursing, and $49 \%$ in obstetric nursing, $57 \%$ in fundamental nursing agreed that the result format gives confidence. Moreover, $47 \%, 45 \%, 68 \%$, and $38 \%$ of students in pediatric, obstetric nursing, fundamental, and medical surgical and critical care nursing agreed that the examination format reduces the chance of failure respectively. Slightly less than one half of the students in obstetric nursing (37\%), $33 \%$ in fundamental nursing, and $43 \%$ in medical surgical and critical care nursing agreed that Examination reflects the level of performance while the opinion of $51 \%$ of students in pediatric nursing was uncertain. The Table also revealed that $44 \%, 54 \%$, and $52 \%$ of students in obstetric, fundamental, medical surgical and critical care nursing agreed that OSPE eliminates the factor of luck respectively while the opinion of $41 \%$ of students in pediatric nursing was uncertain. Furthermore, $53 \%$ of students in obstetric agreed that Scoring was transparent and objective, while the opinion of $44 \%$ and $34 \%$ of students in pediatric and medical surgical and critical care nursing was uncertain while $43 \%$ in fundamental nursing disagreed. Moreover, $47 \%$ of students in pediatric nursing, and $48 \%$ in medical surgical and critical care nursing agreed that OSPE allows more opportunities than the conventional format while the opinion of $50 \%$ of students in obstetric was uncertain, and $48 \%$ in fundamental nursing disagreed.

Table 3. Distribution percent of the students' opinion regarding conduct of objective structured practical examination

\begin{tabular}{|c|c|c|c|c|c|c|c|c|c|}
\hline \multirow[t]{2}{*}{ Conduct of examination } & \multirow[t]{2}{*}{ Agreement } & \multicolumn{2}{|c|}{$\begin{array}{l}\text { Pediatric } \\
\text { nursing }\end{array}$} & \multicolumn{2}{|c|}{$\begin{array}{l}\text { Obstetric } \\
\text { nursing }\end{array}$} & \multicolumn{2}{|c|}{$\begin{array}{l}\text { Fundamental } \\
\text { nursing }\end{array}$} & \multicolumn{2}{|c|}{$\begin{array}{l}\text { Med-Surgical \& Critical } \\
\text { Care Nursing }\end{array}$} \\
\hline & & n & $\%$ & $\mathbf{n}$ & $\%$ & $\mathbf{n}$ & $\%$ & $\mathbf{n}$ & $\%$ \\
\hline \multirow{3}{*}{$\begin{array}{l}\text { Examination format was mor } \\
\text { e stress free }\end{array}$} & Agree & 62 & 62.0 & 51 & 51.0 & 65 & 65.0 & 69 & 69.0 \\
\hline & Uncertain & 27 & 27.0 & 37 & 37.0 & 17 & 17.0 & 22 & 22.0 \\
\hline & Disagree & 11 & 11.0 & 12 & 12.0 & 8 & 8.0 & 9 & 9.0 \\
\hline \multirow{3}{*}{$\begin{array}{l}\text { Variety of structured } \\
\text { templates }\end{array}$} & Agree & 34 & 34.0 & 38 & 38.0 & 50 & 50.0 & 39 & 39.0 \\
\hline & Uncertain & 52 & 52.0 & 47 & 47.0 & 28 & 28.0 & 40 & 40.0 \\
\hline & Disagree & 14 & 14.0 & 15 & 15.0 & 12 & 12.0 & 21 & 21.0 \\
\hline \multirow{3}{*}{$\begin{array}{l}\text { Teacher's absence at stations } \\
\text { was fright free }\end{array}$} & Agree & 33 & 33.0 & 38 & 38.0 & 50 & 50.0 & 39 & 39.0 \\
\hline & Uncertain & 41 & 41.0 & 39 & 39.0 & 18 & 18.0 & 45 & 45.0 \\
\hline & Disagree & 26 & 26.0 & 23 & 23.0 & 22 & 22.0 & 16 & 16.0 \\
\hline \multirow{3}{*}{$\begin{array}{l}\text { There is no interruption in the } \\
\text { stations }\end{array}$} & Agree & 30 & 30.0 & 34 & 34.0 & 50 & 50.0 & 50 & 50.0 \\
\hline & Uncertain & 43 & 43.0 & 36 & 36.0 & 22 & 22.0 & 18 & 18.0 \\
\hline & Disagree & 27 & 27.0 & 30 & 30.0 & 18 & 18.0 & 32 & 32.0 \\
\hline \multirow{3}{*}{$\begin{array}{l}\text { The presence of examiner on } \\
\text { each station facilitated the } \\
\text { exam }\end{array}$} & Agree & 41 & 41.0 & 45 & 45.0 & 69 & 69.0 & 47 & 47.0 \\
\hline & Uncertain & 38 & 38.0 & 34 & 34.0 & 15 & 15.0 & 38 & 38.0 \\
\hline & Disagree & 21 & 21.0 & 21 & 21.0 & 6 & 6.0 & 15 & 15.0 \\
\hline
\end{tabular}

Table 5 shows the distribution percentage of students' opinion regarding the problems and solutions of Objective Structured Practical Examination. Table 5 revealed that $73 \%, 69 \%$, $51 \%$, and $64 \%$ of students in pediatric, obstetric, fundamental, and medical surgical and critical care nursing agreed that OSPE needs more time in each station respectively. Moreover, $43 \%$ of students in pediatric nursing, $43 \%$ in obstetric nursing, $69 \%$ in fundamental nursing, and $36 \%$ in medical surgical and critical care nursing agreed that OSPE exam needs feedback. Furthermore, $43 \%$ and $47 \%$ of students in pediatric and medical surgical and critical care nursing agreed that the number of stations should be limited, while the opinion of $41 \%$ of students in obstetric nursing was uncertain, and $37 \%$ in fundamental nursing disagreed.

Table 6 shows the mean score of students' opinion in relation to the Objective Structured Practical Examination Charac- 
teristics. The mean score of students' opinion in relation to the structure and format of examination was $16.12 \pm 5.45$ in pediatric nursing, $15.9 \pm 5.12$ in obstetric nursing, 16.5 \pm 5.6 in fundamental nursing, and $16.1 \pm 5.1$ in medical surgical and critical care nursing. Regarding the conduct of examination, the mean score was $10.73 \pm 4.56$ in pediatric nursing, $10.2 \pm 4.1$ in obstetric nursing, $10.89 \pm 4.5$ in fundamental nursing, and $9.9 \pm 4.2$ in medical surgical and critical care nursing. In relation to Evaluation of examina- tion, the mean score was $18.41 \pm 5.87$ in pediatric nursing, $18.11 \pm 5.6$ in obstetric nursing, $18.5 \pm 5.98$ in fundamental nursing, and $18.32 \pm 5.7$ in medical surgical and critical care nursing. With regard to the OSCE problems and solutions, the mean score was $7.94 \pm 1.85$ in pediatric nursing, $7.67 \pm$ 1.74 in obstetric nursing, $7.8 \pm 1.79$ in fundamental nursing, and $7.58 \pm 1.68$ in medical surgical and critical care nursing. There was no statistical significant difference among the four groups $(p=1.000)$.

Table 4. Distribution percentage of students opinion regarding evaluation of objective structured practical examination

\begin{tabular}{|c|c|c|c|c|c|c|c|c|c|}
\hline \multirow{2}{*}{$\begin{array}{l}\text { Evaluation of } \\
\text { examination }\end{array}$} & \multirow[t]{2}{*}{ Agreement } & \multicolumn{2}{|c|}{$\begin{array}{l}\text { Pediatric } \\
\text { Nursing }\end{array}$} & \multicolumn{2}{|c|}{$\begin{array}{l}\text { Obstetric } \\
\text { Nursing }\end{array}$} & \multicolumn{2}{|c|}{$\begin{array}{l}\text { Fundamental } \\
\text { Nursing }\end{array}$} & \multicolumn{2}{|c|}{$\begin{array}{l}\text { Med-Surgical \& } \\
\text { Critical Care Nursing }\end{array}$} \\
\hline & & $\mathbf{n}$ & $\%$ & $\mathbf{n}$ & $\%$ & n & $\%$ & $\mathbf{n}$ & $\%$ \\
\hline \multirow{3}{*}{$\begin{array}{l}\text { Examination reduces } \\
\text { the subjectivity }\end{array}$} & Agree & 59 & 59.0 & 48 & 48.0 & 36 & 36.0 & 60 & 60.0 \\
\hline & Uncertain & 22 & 22.0 & 27 & 27.0 & 31 & 31.0 & 32 & 32.0 \\
\hline & Disagree & 19 & 19.0 & 25 & 25.0 & 23 & 23.0 & 8 & 8.0 \\
\hline \multirow{3}{*}{$\begin{array}{l}\text { Examination reflects } \\
\text { the level of } \\
\text { performance }\end{array}$} & Agree & 33 & 33.0 & 37 & 37.0 & 33 & 33.0 & 43 & 43.0 \\
\hline & Uncertain & 51 & 51.0 & 35 & 35.0 & 29 & 29.0 & 28 & 28.0 \\
\hline & Disagree & 16 & 16.0 & 28 & 28.0 & 28 & 28.0 & 29 & 29.0 \\
\hline \multirow{3}{*}{$\begin{array}{l}\text { OSPE eliminates factor } \\
\text { of luck }\end{array}$} & Agree & 39 & 39.0 & 44 & 44.0 & 54 & 54.0 & 52 & 52.0 \\
\hline & Uncertain & 41 & 41.0 & 38 & 38.0 & 22 & 22.0 & 28 & 28.0 \\
\hline & Disagree & 20 & 20.0 & 18 & 18.0 & 14 & 14.0 & 20 & 20.0 \\
\hline \multirow{3}{*}{$\begin{array}{l}\text { Result format gives } \\
\text { confidence }\end{array}$} & Agree & 39 & 39.0 & 49 & 49.0 & 57 & 57.0 & 51 & 51.0 \\
\hline & Uncertain & 34 & 34.0 & 38 & 38.0 & 21 & 21.0 & 37 & 37.0 \\
\hline & Disagree & 27 & 27.0 & 13 & 13.0 & 12 & 12.0 & 12 & 12.0 \\
\hline \multirow{3}{*}{$\begin{array}{l}\text { Scoring was transparent } \\
\text { and objective }\end{array}$} & Agree & 34 & 34.0 & 53 & 53.0 & 28 & 28.0 & 48 & 48.0 \\
\hline & Uncertain & 44 & 44.0 & 28 & 28.0 & 19 & 19.0 & 34 & 34.0 \\
\hline & Disagree & 22 & 22.0 & 19 & 19.0 & 43 & 43.0 & 18 & 18.0 \\
\hline \multirow{3}{*}{$\begin{array}{l}\text { This format reduces } \\
\text { chance of failure }\end{array}$} & Agree & 47 & 47.0 & 45 & 45.0 & 68 & 68.0 & 38 & 38.0 \\
\hline & Uncertain & 34 & 34.0 & 36 & 36.0 & 13 & 13.0 & 36 & 36.0 \\
\hline & Disagree & 19 & 19.0 & 19 & 19.0 & 9 & 9.0 & 26 & 26.0 \\
\hline \multirow{3}{*}{$\begin{array}{l}\text { Allows more } \\
\text { opportunities than the } \\
\text { conventional format }\end{array}$} & Agree & 47 & 47.0 & 34 & 34.0 & 29 & 29.0 & 48 & 48.0 \\
\hline & Uncertain & 38 & 38.0 & 50 & 50.0 & 13 & 13.0 & 36 & 36.0 \\
\hline & Disagree & 15 & 15.0 & 16 & 16.0 & 48 & 48.0 & 16 & 16.0 \\
\hline
\end{tabular}

Table 5. Distribution percentage of students' opinion regarding problems and solutions of objective structured practical examination

\begin{tabular}{|c|c|c|c|c|c|c|c|c|c|}
\hline \multirow{2}{*}{$\begin{array}{l}\text { Problems and } \\
\text { solutions }\end{array}$} & \multirow[t]{2}{*}{ Agreement } & \multicolumn{2}{|c|}{$\begin{array}{l}\text { Pediatric } \\
\text { Nursing } \\
\end{array}$} & \multicolumn{2}{|c|}{$\begin{array}{l}\text { Obstetric } \\
\text { Nursing } \\
\end{array}$} & \multicolumn{2}{|c|}{$\begin{array}{l}\text { Fundamental } \\
\text { Nursing }\end{array}$} & \multicolumn{2}{|c|}{$\begin{array}{l}\text { Med-Surgical \& } \\
\text { Critical Care nursing }\end{array}$} \\
\hline & & $\mathbf{n}$ & $\%$ & $\mathbf{n}$ & $\%$ & $\mathbf{n}$ & $\%$ & $\mathbf{n}$ & $\%$ \\
\hline \multirow{3}{*}{$\begin{array}{l}\text { Needed more time } \\
\text { at each station }\end{array}$} & Agree & 73 & 73.0 & 69 & 69.0 & 51 & 51.0 & 64 & 64.0 \\
\hline & Uncertain & 21 & 21.0 & 16 & 16.0 & 19 & 19.0 & 26 & 26.0 \\
\hline & Disagree & 6 & 6.0 & 15 & 15.0 & 20 & 20.0 & 10 & 10.0 \\
\hline \multirow{3}{*}{$\begin{array}{l}\text { Limit number of } \\
\text { stations }\end{array}$} & Agree & 43 & 43.0 & 36 & 36.0 & 24 & 24.0 & 47 & 47.0 \\
\hline & Uncertain & 42 & 42.0 & 41 & 41.0 & 29 & 29.0 & 30 & 30.0 \\
\hline & Disagree & 15 & 15.0 & 23 & 23.0 & 37 & 37.0 & 23 & 23.0 \\
\hline \multirow{3}{*}{$\begin{array}{l}\text { Feedback and } \\
\text { VOSPE }\end{array}$} & Agree & 43 & 43.0 & 43 & 43.0 & 69 & 69.0 & 36 & 36.0 \\
\hline & Uncertain & 30 & 30.0 & 33 & 33.0 & 15 & 15.0 & 32 & 32.0 \\
\hline & Disagree & 27 & 27.0 & 24 & 24.0 & 6 & 6.0 & 32 & 32.0 \\
\hline
\end{tabular}


Table 6. The mean score of students' opinion in relation to the objective structured practical examination characteristics

\begin{tabular}{|c|c|c|c|c|c|}
\hline $\begin{array}{l}\text { OSPE } \\
\text { Characteristics }\end{array}$ & $\begin{array}{l}\text { Pediatric } \\
\text { Nursing }\end{array}$ & $\begin{array}{l}\text { Obstetric } \\
\text { Nursing }\end{array}$ & $\begin{array}{l}\text { Fundamental } \\
\text { Nursing }\end{array}$ & $\begin{array}{l}\text { Med-Surgical\& Critical } \\
\text { Care Nursing }\end{array}$ & $p$-value \\
\hline $\begin{array}{l}\text { Structure/Format } \\
\text { Mean } \pm \text { SD }\end{array}$ & $16.12 \pm 5.45$ & $15.9 \pm 5.12$ & $16.5 \pm 5.6$ & $16.01 \pm 5.1$ & 1.000 \\
\hline $\begin{array}{l}\text { Conduct of examination } \\
\text { Mean } \pm \text { SD }\end{array}$ & $10.73 \pm 4.56$ & $10.2 \pm 4.1$ & $10.89 \pm 4.5$ & $9.9 \pm 4.2$ & 1.000 \\
\hline $\begin{array}{l}\text { Evaluation of examination } \\
\text { Mean } \pm \text { SD }\end{array}$ & $18.41 \pm 5.87$ & $18.11 \pm 5.6$ & $18.5 \pm 5.98$ & $18.32 \pm 5.7$ & 1.000 \\
\hline $\begin{array}{l}\text { Problems and solutions } \\
\text { Mean } \pm \text { SD }\end{array}$ & $7.94 \pm 1.85$ & $7.67 \pm 1.74$ & $7.8 \pm 1.79$ & $7.58 \pm 1.68$ & 1.000 \\
\hline
\end{tabular}

\section{Discussion}

Objective Structured Practical Evaluation is considered by somewhat a golden standard for assessing pre-clinical laboratory skills. It appears to be important for performance discrimination on the basis of individual competency, and attitude towards learning. It may not only improve the quality of students' performance in the laboratory exercise but may also prepare them for their clinical years so that good clinicians may be produced. The OSPE is the modified version of the OSCE used for a summative assessment of practical knowledge and skills in basic sciences. ${ }^{[6]}$ The current study shows that the majority of students $(86 \%, 89 \%, 84 \%$, and $80 \%$ ) were females in pediatric, obstetric, fundamental, medical surgical and critical care nursing respectively. Similar results by Hatamleh and Sabeeb (2015) revealed that the majority of the respondents were females $(85.5 \%){ }^{[12]}$

The current study reported that the majority of the students in pediatric, obstetric, fundamental, medical surgical and critical care nursing agreed that instructions were adequate, opportunity for clarification in examination, uniformity of questions, examination covered all types of questions, examination was well-structured and sequenced, examination time allocated was appropriate, and examination was wellorganized. These results are consistent with Benita, and Nabanika (2015) ${ }^{[13]}$ who revealed that the majority of students provided a positive perception towards information received on OSPE. In another study done by Malhotra et al. (2013), ${ }^{[14]}$ they reported that the majority of students provided a positive view about clarity of the instruction of examination. Also, Pakhale et al. (2012) ${ }^{[11]}$ noted that the OSPE environment was fair in relation to the uniformity of questions and time allocated. The result done by Ameh et al. $(2014)^{[15]}$ reported that the students felt that the OSPE covers a wider range of topics than the TCE and allows them to make up for any areas they may have performed poorly. In the same line, Hatamleh W, and Sabeeb (2015) ${ }^{[12]}$ stated that the OSPE examination was well-structured and sequenced. In addition, Nasir et al. (2015) ${ }^{[18]}$ emphasized that the OSPE stations were appropriate in relation to the time allocated and properly organized. On the other hand, Ameh et al. (2014) ${ }^{[15]}$ reported that the students found a difficulty in management of time in some stations, so they demonstrated more time to be given for these stations probably for the lack of practice.

In the current study, the majority of students in pediatric, obstetric, fundamental, and medical surgical and critical care nursing agreed that examination format was more stress free. Several studies reported that the criteria of a good examination include a relaxed environment. It was felt that the OSPE is one of the choices that fit into these criteria. ${ }^{[13,17,18]}$ On the other hand, Goud et al. (2014) ${ }^{[19]}$ found that half of the students agreed and the other half disagreed that OSPE is a stressful examination. The present study revealed that less than half of the students in pediatric nursing, obstetric, and medical surgical and critical care nursing agreed that there was a variety of structured templates in examination and teacher's absence at stations was fright free. This study was supported by Pakhale et al. (2012) ${ }^{[11]}$ who reported that half of the students agreed that the variety of structured templates, and the teachers' absence at stations was fright free. On the hand, Radhika et al. (2015) ${ }^{[20]}$ revealed that the majority of the students agreed that the variety transparency of structured templates, and the teachers' absence at the stations were fright free. Also, the current study founded that less than half of the students in pediatric, obstetric, and medical surgical and critical care nursing agreed that the presence of examiner in each station facilitates the exam. The study was somewhat similar to the Nasir et al. $(2015)^{[16]}$ who stated that there was a significant association between students of different levels for the presence of examiner in each station facilitated their exam.

The current study revealed that more than half of the students in pediatric, and medical surgical and critical care nursing agreed that examination reduces the subjectivity respectively. Moreover, more than half of the students in fundamental, medical surgical and critical care nursing agreed that OSPE eliminates the factor of luck, and result format gives confidence while the opinion of slightly more than half of students' 
in obstetric nursing agreed that the scoring was transparent and objective. Furthermore, more than half of the students in fundamental nursing agreed that the examination format reduces the chance of failure. Several studies revealed that the criteria of a good examination include validity, objectivity, practicability, relevance, promotion of learning, and eliminate the factors of luck, and power to discriminate between students. It was felt that the OPSE is one of the choices that fit into these criteria. ${ }^{[9,12,14,16-18]}$ In another study, done by Goud et al. (2014), ${ }^{[19]}$ it was noted that the student feedback about methodologies is useful for modifying and improving medical education. The ultimate aim of such feedback is to identify areas of strength and weakness in teaching methodology used so that steps can be taken to rectify the deficiencies and to evolve the curriculum and achieve the intended goals. Also, this result was supported by Eldarir and Hamid (2013) ${ }^{[21]}$ who found that the students who got higher scores in OSCE assessment method were much more self-confident in doing clinical practice.

The current study reported that slightly less than one third of the students in obstetric, fundamental nursing, medical surgical and critical care nursing agreed that Examination reflects the level of performance while half of the students' opinion in pediatric nursing was uncertain. These findings are contradicted with Ali (2012) ${ }^{[18]}$ who said that the students view positively towards the validity and reliability of OSCE scoring system. Also, the current study revealed that slightly less than half of students in pediatric, and medical surgical and critical care nursing agreed that OSPE allows more opportunities than the conventional format while the opinion of half of the students in obstetric was uncertain, and less than half of the students in fundamental nursing disagreed. These results are consistent with Abraham et al. (2009) ${ }^{[22]}$ who concluded that the students were in favor of the OSPE compared with traditional practical examinations. Also, Malhotra et al. (2013) ${ }^{[14]}$ emphasized that as far as the students' perception with regard to the difficulty level are concerned, only about $10 \%$ of the students perceived OSPE as more difficult than clinical practical examination (CPE); Suggesting that it would be acceptable to the majority of students if it replaces CPE.

The current study revealed that the majority of students in pediatric, obstetric, fundamental, and medical surgical and critical care nursing agreed that OSPE needs more time at each station. These findings are convenient with Mahotra et al. (2013) $)^{[14]}$ who reported that the time allocated for conducting OSPE was also less, as perceived by a majority (95\%) of the students. Also, the time allocated for conducting OSPE was reduced compared to CPE.
In the present study, slightly less than half of students in pediatric and medical surgical and critical care nursing agreed that the number of stations should be limited. Similar results by Mathews (2004) ${ }^{[23]}$ concluded that micro OSCE with two stations was satisfactory, as a formative method of assessment in pediatrics. On the other hand, Mahotra et al. (2013) $)^{[14]}$ founded OSPE with five stations, which could affect the reliability of the test. As OSPE was planned for a formative assessment, the researcher planned only five stations with five minutes for each. It is believed that with a single experience, with a limited number of stations, it is not possible to judge the difficulties and constraints of using OSPE as a method to assess the complete course on a regular base.

In the current study, the majority in fundamental nursing agreed that OSPE exam should be included. These results are consistent with Kumar $(2016)^{[24]}$ who reported that the OSPE is a feasible method which can be implemented in the health sciences in marking, can be used as a digital study material with concern and also as an evidence of student performance interview process.

The current study concluded that there were no significant differences in the mean score of students' opinion in relation to structure and format of examination, conduct of examination, evaluation of examination, and problems compared with the four departments (pediatric, obstetric, fundamental, medical surgical and critical care nursing) $(p=1.000)$. On the other hand, Nasir et al. (2015) ${ }^{[16]}$ concluded that was a significant difference in the mean evaluation score when compared with the three branches after applying multiple comparison tests, and a significant difference was observed between the mean evaluation scores of public health and dental students, showing that the former were more satisfied with the evaluation as compared to the latter.

\section{Conclusion}

Students in Pediatric, Obstetric, Fundamental, Medical Surgical and Critical Care Nursing Departments preferred OSPE as a method of assessing clinical skills and perceived it as more organized, objective, structured, valid, and less anxious. Student's feedback was invaluable regarding needing more time in each station. Also, students provided several suggestions for promoting the quality of OSPE in an assessment process.

\section{Recommendations for future practice}

Based on the findings of the current study, it is recommended that:

(1) OSPE using as an integral part of the overall assessment strategy at the four years under graduate educa- 
tional programs.

(2) The management process involved during an OSPE must be studied in relation to instructor's preparation, and student's feedback.

(3) Videotaped OSPE is a feasible method when imple- mented in the nursing curriculum.

\section{CONFLICTS OF INTEREST DisClOSURE}

The authors declare that there is no conflict of interest.

\section{REFERENCES}

[1] Mater E, Ahmed E, ElSayed A, et al. The Impact of the Objective Structured Clinical Examination Approach for Clinical Evaluation Skills on the Student's Performance in Nursing College. World Journal of Medical Sciences. 2014; 11 (4): 609-613.

[2] Bashir A, Tahir S, Khans. Objectively Structured Performance Evaluation - A learning tool. Biomedica Journal. 2014; 30(2).

[3] Ahmad C, Ahmad N, Baker R. Assessing Nursing Clinical Skills Performance Using Objective Structured Clinical Examination (OSCE) for Open Distance Learning Students in Open University Malaysia. International Conference on Information; Kuala Lumpur. 2009; 12 13.

[4] Hassan M, Yacoubi A. Medical students' perception of the proposal for theme-based integrated multi-disciplinary objective structured practical examination in Saudi Arabia. Journal of Research in Nursing and Midwifery (JRNM). 2015; 4(3): 47-52.

[5] Al Mously N, Nabil NM, Salem R. Student feedback on OSPE: An experince of a new medical school in Soudia Arabia. Medical Science Educator Journal. 2012; 22(1): 10-16. http://dx. doi .org $/ 10.1007 / \mathrm{BF} 03341746$

[6] Soliman H, sheble A, Shrief W. Effectiveness of Simulation training on clinical Nursing Education and competence: Randomized Controlled Trial. International Journal of Advanced Research. 2014; 2(4): 387-393.

[7] Bayoumy M, Yousri H. Objective Structured Clinical Examination (OSCE)-Based Assessment in Nursing: Students' and Clinical. Journal of American Science. 2012; 8(9): 523.

[8] Health Workforce Development (HWD) Project Final report, Baseline survey- part I: Assessment of competency resulting from medical and nursing education in Egypt. Egypt Health Workforce Development Project. May 2006.

[9] Pinaki W, Vrinda D. Objective structure practical examination versus traditional clinical examination in human physiology: Student's perception. International Journal of Medical Science and Public Health. 2013; 3(2): 543

[10] Kim J. Relationships between the Objective Structured Clinical Examination, Depression Cognitive Scale, Self-Efficacy, and Problem Solving Strategies of Sophomore Nursing Students. International Journal of Bio-Science and Bio-Technology. 2013; 5(4).

[11] Pakhale S, Mahajan A, Fating A, et al. Study of student's perception regarding increasing objectivity during practical examination in anatomy. International Journal of Health Science and Research. 2012; 2(4): 48-53.

[12] Hatamleh W, Sabeeb Z. Nursing student's perceptions of an objectives structured clinical examination. International Journal of Health Care Sciences. 2015; 2(2): 52-56.

[13] Benita D, Nabanika K. Nursing students' perception of objective structured practical examination (OSPE) in a selected institute, Guwa- hati, Assam. International Journal of Nursing Education. 2015; 7(3): 192-196. http://dx.doi.org/10.5958/0974-9357.2015.001 63.4

[14] Mahotra S, Shah K, Patel V. Objective structured practical examination as a tool for the formative assessment of practice skills of undergraduate students in pharmacology. Journal of Educ Health Promot. 2013; 2: 53. PMid:24251289 http://dx.doi.org/10.4103 /2277-9531.119040

[15] Ameh N, Abdul M, Adesiyun G, et al. Objective structured clinical examination versus clinical examination an evaluation of students' perception and preference in a Nigerian Medical School. Niger Med Journal. 2014; 55(4): 310-313. PMid:25114366 http: //dx.doi.org/10.4103/0300-1652.137191

[16] Nasir N, Asad M, Sami W, et al. Student's perception on objective structured practical examination in college of Applied Medical Sciences. International Journal of Advanced Research. 2015; 3(6): 535-540.

[17] Lakshmipathy K. MBBS student perceptions about physiology subject teaching and objective structured practical examination based formative assessment for improving competencies. Adv. Physio. Educ. 2015; 39: 198-204. PMid:26330038 http://dx.doi .org/10.11 52/advan.00073.2014

[18] Ali G, Mehdi A, Ali H. Objective structured clinical examination OSCE as an assessment tool for clinical skills in Sohag University: Nursing Students' perceptive. Journal of Environmtal Studies. 2012; 8: 59-69.

[19] Goud BKM, Begum S, ZakinB, et al. Perceptions and performance of undergraduate medical students in objective structured practical examinations OSPE in Biochemistry at RAK Medical and Health Services University, UAE. Journal of Universal College of medical Science. 2014; 2(8): 4.

[20] Radhika G, Dara A, Varalaxmi K, et al. Perceptions of the introduction of objective structured practical examination OSPE/ objective structured clinical examination OSCE: A pilot study carried out in Government Medical College. Anathapuramu, Andhra Pradesh, India. 2015; 9(3): 145-149.

[21] Eldarir S, Hamid N. Objective structured clinical evaluation versus traditional clinical student's achievement at maternity nursing: A comparative approach. Journal of Dental and Medical Sciences. 2013; 4(3): 63-68. http://dx.doi .org/10.9790/0853-0436368

[22] Abraham RR, Raghavendra R, Surekha K, et al. A trail of the objective structured practical examination in phisiology at Melaka Manipal Medical College. India. Adv Physid Edu Journal. 2009; 33: 21-23.

[23] Mathews L, Menon J, Mani NS. Micro OSCE for assessment of undergraduates. Indian Pediatr Journal. 2004; 41: 159-63.

[24] Kumar R. Videotaped OSPE: Is this a right procedure to assess health science student's performances? Apilot study. International Journal of Information and Education Technology. 2016; 6(3). 